\title{
Microhardness and Fluoride Release of Restorative Materials in Different Storage Media
}

\author{
Kélio Garcia SILVA ${ }^{1}$ \\ Denise PEDRINI ${ }^{2}$ \\ Alberto Carlos Botazzo DELBEM ${ }^{1}$ \\ Mark CANNON ${ }^{3}$ \\ ${ }^{1}$ Department of Pediatric and Social Dentistry, São Paulo State University, \\ School of Dentistry of Araçatuba, Araçatuba, SP, Brazil \\ ${ }^{2}$ Department of Surgery and Integrated Clinic, São Paulo State University, \\ School of Dentistry of Araçatuba, Araçatuba, SP, Brazil \\ ${ }^{3}$ Childrens' Memorial Hospital, Northwestern University, Chicago, IL, USA
}

\begin{abstract}
This study evaluated the surface microhardness and fluoride release of 5 restorative materials - Ketac-Fil Plus, Vitremer, Fuji II LC, Freedom and Fluorofil - in two storage media: distilled/deionized water and a pH-cycling (pH 4.6). Twelve specimens of each material, were fabricated and the initial surface microhardness (ISM) was determined in a Shimadzu HMV-2000 microhardness tester (static load Knoop). The specimens were submitted to 6- or 18-h cycles in the tested media. The solutions were refreshed at the end of each cycle. All solutions were stored for further analysis. After 15-day storage, the final surface microhardness (FSM) and fluoride release were measured. Fluoride dose was measured with a fluoride-specific electrode (Orion 9609-BN) and digital ion analyzer (Orion 720 A). The variables ISM, FSM and fluoride release were analyzed statistically by analysis of variance and Tukey's test $(p<0.05)$. There was significant difference in FSM between the storage media for Vitremer $(\mathrm{pH} 4.6=40.2 \pm 1.5$; water $=42.6 \pm 1.4)$, Ketac-Fil Plus $(\mathrm{pH} 4.6$ $=73.4 \pm 2.7$; water $=58.2 \pm 1.3)$ and Fluorofil $(\mathrm{pH} 4.6=44.3 \pm 1.8$; water $=38.4 \pm 1.0)$. Ketac-Fil Plus $(9.9 \pm 18.0)$ and Fluorofil $(4.4$ \pm 1.3 ) presented higher fluoride release in water, whereas Vitremer (7.4 \pm 7.1$)$, Fuji II LC (5.7 \pm 4.7$)$ and Freedom (2.1 \pm 1.7$)$ had higher fluoride release at $\mathrm{pH}$ 4.6. Microhardness and fluoride release of the tested restorative materials varied according to the storage medium.
\end{abstract}

Key Words: hardness, fluoride, in vitro, dental material, $\mathrm{pH}$-cycling.

\section{INTRODUCTION}

Currently, investigations aim at developing materials whose characteristics may meet the expectations of both dentist and patient, such as mechanical strength, good marginal fit and esthetics, associated with ease of handling and accesible costs. The oral cavity is a complex environment and thus influences the properties of restorative materials (1). In vitro studies attempt to reproduce the oral characteristics by investigation of these properties. However, the different methodologies and measurements impair evaluations and comparisons (2-7). Most studies are related to fluoride release and indicate that the storage media should be considered, as acidic solutions have been shown to favor the release, unlike remineralizing solutions, water or artificial saliva $(4,5,8)$. Although water is the most employed storage medium, current studies have preferred to employ methodologies that simulate the oral environment, in order to provide data closer to reality and reproduce clinical situations.

Models using $\mathrm{pH}$-cycling are able to simulate the cariogenic activity in which there is a dynamics of demineralization and remineralization. Several studies have been conducted (9-11) and some modifications have been introduced in these models to provide support

Correspondence: Profa. Dra. Denise Pedrini, Departamento de Cirurgia e Clínica Integrada, Faculdade de Odontologia de Araçatuba, UNESP, Rua José Bonifácio, 1193, Vila Mendonça, 16015-050 Araçatuba, SP, Brasil. Tel: +55-18-3636-3240. Fax: +55-18-3636-3332. e-mail: pedrini@foa.unesp.br 
to methodologies employing bovine teeth for evaluation of the anticariogenic activity of fluoride-releasing restorative materials (12).

Thus, it would be interesting to investigate the performance of restorative materials in different storage media. This study evaluated the surface microhardness and fluoride release of restorative materials stored in distilled/deionized water or in $\mathrm{pH}$-cycling.

\section{MATERIAL AND METHODS}

\section{ExperimentalDesign}

For this study, 12 specimens (5-mm diameter $\mathrm{x}$ 2-mm thick) of each material were fabricated according to the manufacturers' instructions: one conventional glass ionomer cement (Ketac-Fil Plus; 3M/ESPE, Seefeld, Germany); two resin-modified glass ionomer cements (Vitremer; 3M/ESPE, St. Paul, MN, USA and Fuji II LC; GC Corporation, Tokyo, Japan); two polyacid-modified composite resin (Freedom; SDI Limited, Bayswater, Victoria, Australia and Fluorofil - experimental material not available in the market; Bisco, Inc. Schaumburg, IL, USA). The materials were placed into metallic template covered on each side with a polyester strip. A microscope slide coverslip was placed on the top surface and a $175 \mathrm{~g}$ load was applied for extrusion any excess material from the matrix. For the conventional material, this load was maintained for 10 min until initial hardening. A stainless steel wire was incorporated into the materials during setting to suspend the specimens in the testing storage medium. Curing of light-cured materials was performed with a VIP unit (Bisco Inc.) for $40 \mathrm{~s}$ at both sides of the specimen, at a light intensity of 500 $\mathrm{mW} / \mathrm{cm}^{2}$. No polishing was done on specimen surface, which were submitted to the initial surface microhardness (ISM) test, $1 \mathrm{~h}$ after fabrication. During this period and 4 additional hours, the specimens were stored in a plastic container with cover and maintained in a humid environmen, being thereafter submitted to $\mathrm{pH}$-cycling or stored in distilled/deionized water for 15 days. At every 6 and $18 \mathrm{~h}$, the solutions were replaced and stored for measurement of fluoride released. At completion of the study period, the final surface microhardness (FSM) was performed. Variations factors were the restorative materials and storage media, and the variables employed for quantification of the effect were the surface microhardness and amount of fluoride released.

\section{Experimental Groups}

The specimens were randomly placed in polypropylene test tubes with lids. Each tube contained $2 \mathrm{~mL}$ of the demineralizing $(\mathrm{De})$ or remineralizing $(\mathrm{Re})$ solutions or $2 \mathrm{~mL}$ of distilled/deionized water. The specimens were initially stored for $6 \mathrm{~h}$ in De solution $\left(2.0 \mathrm{mmol} \mathrm{L}^{-1} \mathrm{Ca}\right.$ and $\mathrm{P}$, in acetate buffer $75 \mathrm{mmol} \mathrm{L}^{-1}, \mathrm{pH} \mathrm{4.6)} \mathrm{and}$ threreafter placed in new tubes containing Re solution (Ca $1.5 \mathrm{mmol} \mathrm{L}^{-1}, \mathrm{P} 0.9 \mathrm{mmol} \mathrm{L}^{-1}, \mathrm{KCl} 150 \mathrm{mmol} \mathrm{L}^{-1}$ in Tris buffer $20 \mathrm{mmol} \mathrm{L}^{-1}, \mathrm{pH} 7.0$ ) for $18 \mathrm{~h}$. The group of distilled/deionized water followed the same protocol of change of solution as the $\mathrm{pH}$-cycling group ( 6 and $18 \mathrm{~h}$ ). The tubes were subjected to constant shaking (TE-420 Orbital shaking table; Tecnal, Piracicaba, SP, Brazil) and were stored at $37 \pm 1^{\circ} \mathrm{C}$. The specimens were rinsed with distilled/deionized water and dried with absorbent paper before storage in a new solution. The solutions were collected daily, labeled and stored in polypropylene test tubes at $-4^{\circ} \mathrm{C}$ for measurement of fluoride release.

\section{Determination of Initialand Final Surface Microhardness}

The surface microhardness was measured with microhardness meter(Shimadzu HMV-2000 Micro Hardness Tester; Shimadzu Corporation, Kyoto, Japan), under a static load (Knoop) of $100 \mathrm{~g}$ during $5 \mathrm{~s}$. For the ISM, 5 indentations were performed on the top surface of the material at $500 \mu \mathrm{m}$ distance from each other, while for the FSM 5 indentations were performed at 250 $\mu \mathrm{m}$ from the initial indentations.

\section{Determination of Fluoride Released in the Solutions}

Fluoride dose was measured with a fluoridespecific electrode (Orion 9609-BN; Orion Research, Inc., Beverly, MA, USA) and digital ion analyzer (Orion 720 A; Orion Research, Inc.), previously calibrated with standard solutions $(0.0625$ to 1 or 2 to $32 \mu \mathrm{g} \mathrm{F} /$ $\mathrm{mL}$ ), according to the fluoride concentration in the samples expressed in $\mu \mathrm{g} \mathrm{F} / \mathrm{cm}^{2}$. Before reading, TISAB III (Thermo Orion, Beverly, MA, USA) was added at a ratio of 1:10, and the fluoride was dosed while the solution was being constantly shaken (TE-081; Tecnal, Piracicaba, SP, Brazil). Fluoride concentrations in the solutions were determined separately. Afterwards, the results of 6- and 18-h solutions were added, finalizing a 24-h period and one cycle of methodology completed. 


\section{Statistical Analysis}

A normality test was applied to the surface microhardness (ISM/FSM) and fluoride release data. As data distribution was normal, three-way analysis of variance was applied to the surface microhardness (ISM/FSM) results while two-way analysis of variance was applied to the fluoride release results. Tukey's posthoc test was used for multiple comparisons of the means. Analyses were performed with the GMC statistical software package (version 2002: available from http://www.forp.usp.br/restauradora/gmc/gmc.html) at $5 \%$ significance level.

\section{RESULTS}

Table 1 presents the microhardness results according to the storage media for each investigated material. The FSM of Ketac-Fil Plus was reduced in water and Vitremer and Fluorofil presented a reduction in FSM regardless of the storage medium $(p<0.05)$. The other materials presented an increase in FSM and KetacFil Plus at $\mathrm{pH} 4.6(\mathrm{p}<0.05)$. There was statistically significant difference in FSM between storage media for Vitremer, Ketac-Fil Plus and Fluorofil $(\mathrm{p}<0.05)$ but not for Fuji II LC and Freedom ( $p>0.05)$. Table 2 demonstrates the results of fluoride released by restorative materials for the interaction material $\mathrm{x}$ storage medium. All materials evaluated presented fluoride release during the study period. Ketac-Fil Plus and Fluorofil released more fluoride in water, whereas Vitremer, Fuji II LC and
Freedom presented higher fluoride release at medium $\mathrm{pH} 4.6(\mathrm{p}<0.05)$. Ketac-Fil Plus presented the highest fluoride release in water and Vitremer at $\mathrm{pH} 4.6(\mathrm{p}<0.05)$. Among the analyzed materials, Freedom presented the lowest fluoride release in both storage media analyzed $(p<0.05)$. Figure 1 demonstrates the pattern of fluoride release over time and the influence of the storage medium on the different materials. Even though there were differences in the amount of fluoride released from materials, a similar pattern was noted for all materials and storage media. The greatest release occurred at the first $24 \mathrm{~h}$, rapidly decreased and kept lower and nearly constant values up to study completion.

Table 2. Means $( \pm \mathrm{SD} ; \mathrm{n}=6)$ of fluoride concentration $\left(\mu \mathrm{g} \mathrm{F} / \mathrm{cm}^{2}\right)$ for storage medium $\mathrm{x}$ material comparisons.

\begin{tabular}{|c|c|c|c|c|c|}
\hline \multirow{2}{*}{$\begin{array}{l}\text { Storage } \\
\text { media }\end{array}$} & \multicolumn{5}{|c|}{ Material } \\
\hline & Vitremer & $\begin{array}{c}\text { Fuji II } \\
\text { LC }\end{array}$ & $\begin{array}{c}\text { Ketac-Fil } \\
\text { Plus }\end{array}$ & Freedom & Fluorofil \\
\hline $\mathrm{H}_{2} \mathrm{O}$ & $\begin{array}{c}6.4^{\mathrm{c}} \\
( \pm 6.9)\end{array}$ & $\begin{array}{c}5.0^{\mathrm{d}} \\
( \pm 4.4)\end{array}$ & $\begin{array}{c}9.9^{\mathrm{a}} \\
( \pm 18.0)\end{array}$ & $\begin{array}{c}1.2^{\mathrm{h}} \\
( \pm 1.5)\end{array}$ & $\begin{array}{c}4.4^{\mathrm{e}} \\
( \pm 1.3)\end{array}$ \\
\hline $\mathrm{pH} 4.6$ & $\begin{array}{l}7.4^{b} \\
( \pm 7.1)\end{array}$ & $\begin{array}{c}5.7^{\mathrm{c}} \\
( \pm 4.7)\end{array}$ & $\begin{array}{c}5.4^{\mathrm{d}} \\
( \pm 6.3)\end{array}$ & $\begin{array}{c}2.1^{\mathrm{g}} \\
( \pm 1.7)\end{array}$ & $\begin{array}{c}3.0^{\mathrm{f}} \\
( \pm 3.4)\end{array}$ \\
\hline
\end{tabular}

Means followed by different letters indicate statistically significant difference at $5 \%$.

Table 1. Means ( $\pm \mathrm{SD} ; \mathrm{n}=6$ ) of initial (ISM) and final (FSM) surface microhardness for storage medium $\mathrm{x}$ material comparisons.

\begin{tabular}{|c|c|c|c|c|c|c|c|c|c|c|}
\hline \multirow{4}{*}{$\begin{array}{l}\text { Storage } \\
\text { media }\end{array}$} & \multicolumn{5}{|c|}{ Initial Surface Microhardness (ISM) } & \multicolumn{5}{|c|}{ Final Surface Microhardness (FSM) } \\
\hline & \multirow{3}{*}{ Vitremer } & Fuji II & Ketac-Fil & \multirow{3}{*}{ Freedom } & \multirow{3}{*}{ Fluorofil } & \multirow{3}{*}{ Vitremer } & Fuji II & Ketac-Fil & \multirow{3}{*}{ Freedom } & \multirow{3}{*}{ Fluorofil } \\
\hline & & & & & & & & & & \\
\hline & & $\mathrm{LC}$ & Plus & & & & $\mathrm{LC}$ & Plus & & \\
\hline \multirow{2}{*}{$\mathrm{H}_{2} \mathrm{O}$} & $49.3^{\mathrm{d}}$ & $38.2^{\mathrm{f}}$ & $65.9^{\mathrm{b}}$ & $24.2^{\mathrm{h}}$ & $65.2^{b}$ & $42.6^{\mathrm{e}}$ & $48.3^{\mathrm{d}}$ & $58.2^{\mathrm{c}}$ & $30.4^{\mathrm{g}}$ & $38.4^{\mathrm{f}}$ \\
\hline & $( \pm 1.6)$ & $( \pm 2.9)$ & $( \pm 2.1)$ & $( \pm 1.8)$ & $( \pm 0.9)$ & $( \pm 1.4)$ & $( \pm 3.0)$ & $( \pm 1.3)$ & $( \pm 1.8)$ & $( \pm 1.0)$ \\
\hline \multirow{2}{*}{$\mathrm{pH} 4.6$} & $49.2^{d}$ & $38.3^{\mathrm{f}}$ & $65.3^{b}$ & $24.3^{\mathrm{h}}$ & $65.4^{b}$ & $40.2^{\mathrm{f}}$ & $48.3^{\mathrm{d}}$ & $73.4^{\text {a }}$ & $30.6^{\mathrm{g}}$ & $44.3^{\mathrm{e}}$ \\
\hline & $( \pm 1.9)$ & $( \pm 2.4)$ & $( \pm 3.6)$ & $( \pm 2.1)$ & $( \pm 0.8)$ & $( \pm 1.5)$ & $( \pm 3.1)$ & $( \pm 2.7)$ & $( \pm 2.4)$ & $( \pm 1.8)$ \\
\hline
\end{tabular}

Means followed by different letters indicate statistically significant difference at $5 \%$. 

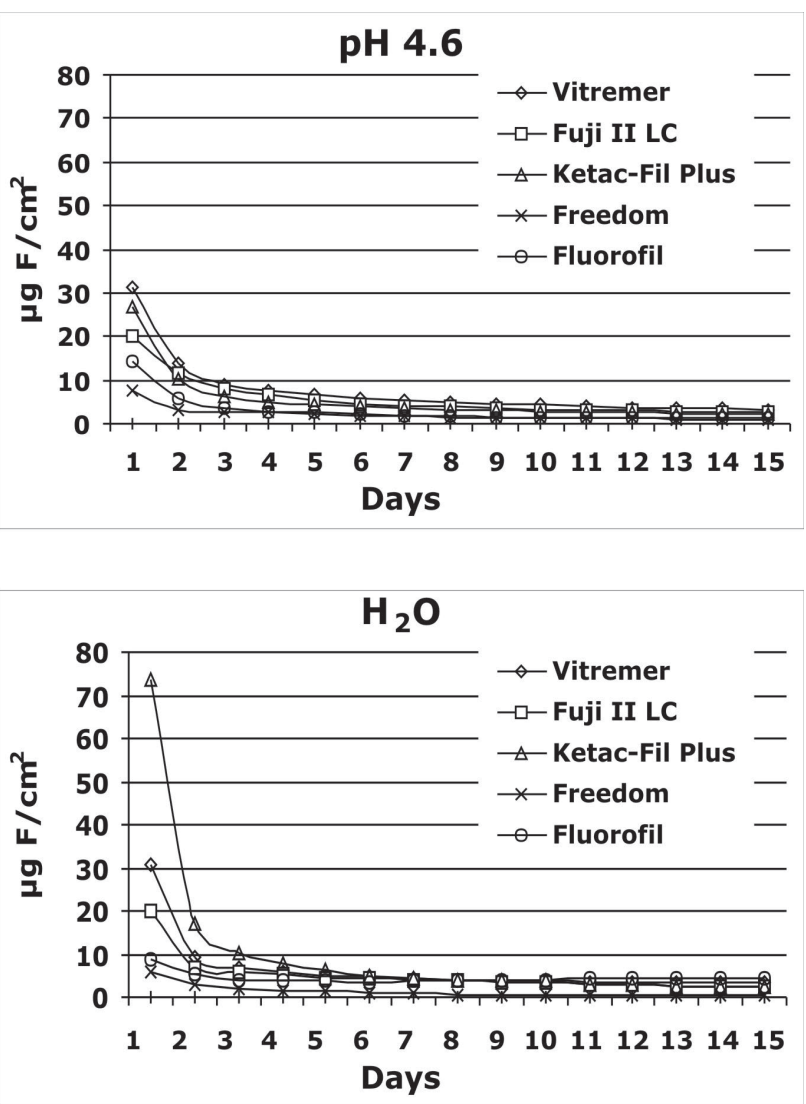

Figure 1. Graphs of fluoride release $\left(\mu \mathrm{g} \mathrm{F} / \mathrm{cm}^{2}\right)$ of the materials at the different storage media along time (days). Top $=\mathrm{pH}$-cycling (pH 4.6); Bottom = distilled/deionized water.

\section{DISCUSSION}

In accomplishment of in vitro studies, the development of laboratory models simulating clinical conditions is interesting in the search for information on the performance of restorative materials in these conditions. Among several factors, the storage medium $(\mathrm{pH}$, temperature and composition) may lead to different performances $(7,13)$. In order to support the methodology of using bovine teeth (12), this study introduced a modification in $\mathrm{pH}$ compared to previous studies (911), since $\mathrm{pH} 4.6$ was employed. This was demonstrated to be an ideal value in the utilization of bovine teeth due to its chemical and structural variation (12), which also provides important data for future studies on enamel remineralization with restorative materials.

After storage of materials in aqueous media, there were changes in surface microhardness accord- ing to the experimental group (Table 1). According to Ellakuria et al. (14) the material may be "harder" or "softer" depending on several factors such as chemical composition, glass structure, concentration and molecular weight of the polycarboxylic acid, proportion of powder/liquid, storage time and type. Probably, an association of these factors provided the different microhardness, leading to an inversion in the outcomes (Table 1). The presence of extended hardening reaction and water sorption by contact with the aqueous solution after initial hardening affects the microhardness (15). Probably, this led to lower microhardness when the conventional glass ionomer cement was stored in water.

As previously described $(2,6)$, the greatest release is observed on the first day of storage. After that time, a progressive and gradual decrease in release rate occurs until the seventh storage day. After that period the release becomes extremely low but constant with time, also observed in our study (Figure 1). With regard to the pattern of fluoride release, regardless of the storage medium, the conventional and resin-modified glass ionomer cements presented higher fluoride release than polyacid-modified composite resins (Table 2 and Figure 1). Analysis of each material shows differences with the change in storage medium, not revealing a pattern of release (Table 2). The tests performed in deionized water quantified the total release of fluoride ions in the medium, without interference from saliva, i.e., without the ionic force of several other elements existing in saliva (16). Several studies $(4,5,8,17)$ have shown that fluoride release seems to be $\mathrm{pH}$ dependent and is influenced by the type of media used. Moreover, it has been shown that differences between chemical and physical properties of the studied materials exert large influence on fluoride release (18), as that it was not verified a similar pattern for the tested materials. Thus, the medium interact with the material influencing the mechanisms of fluoride release, erosion and ions diffusion $(5,6,18-20)$. This might explain the contradictory findings of some studies while comparing their results, inasmuch as the media may either benefit or inhibit fluoride release from materials, making them having an opposite behavior depending on the used storage medium.

Therefore, the results of this study demonstrated that the properties of restorative materials varied according to the storage medium, highlighting the importance of accomplishment of in vitro studies that simulate the oral environment for standardization and com- 
parison of results, for achievement of more reliable data. Studies evaluating the anticariogenic activities of restorative materials should allow observation of performance close to the in vivo situation. Changes in methodologies of pH-cycling (12) may lead to different performance among different materials. Thus, these $\mathrm{pH}$-cycling models should be validated for studies, for observation of inhibition of demineralization and activation of remineralization by fluoride-releasing materials.

In conclusion, the microhardness and fluoride release of restorative materials investigated in the present study varied according to the storage medium.

\section{RESUMO}

Este estudo avaliou as propriedades de microdureza de superfície e liberação de flúor de 5 materiais restauradores (Ketac-Fil Plus, Vitremer, Fuji II LC, Freedom e Fluorofil) em dois meios de imersão: água destilada/deionizada e modelo de ciclagem de $\mathrm{pH}$ $(4,6)$. Doze corpos-de-prova de cada material foram confeccionados e tiveram a microdureza de superfície inicial (MSI) determinada utilizando o microdurômetro Shimadzu HMV-2000 Micro Hardness Tester (carga estática Knoop). Os corpos-de-prova foram submetidos a ciclos de 6 e $18 \mathrm{~h}$ para os dois meios de imersão. A cada final de ciclo as soluções foram substituídas e armazenadas. Após 15 dias de imersão, a microdureza de superfície final (MSF) e a liberação de flúor foram determinadas. A dosagem de flúor foi feita com um eletrodo específico combinado para íon flúor (9609 BN - Orion) e analisador de íons digital (Orion 720 A). As variáveis MSI, MSF e liberação de flúor foram submetidas à análise de variância e teste de Tukey $(\mathrm{p}<0,05)$. Houve diferença estatisticamente significante na MSF entre os meios de imersão para o Vitremer $(\mathrm{pH} 4,6=40,2 \pm 1,5$; água $=42,6 \pm 1,4)$, KetacFil Plus ( $\mathrm{pH} 4,6=73,4 \pm 2,7$; água $=58,2 \pm 1,3)$ e Fluorofil $(\mathrm{pH}$ $4,6=44,3 \pm 1,8$; água $=38,4 \pm 1,0)$. O Ketac-Fil Plus $(9,9 \pm 18,0)$ e o Fluorofil $(4,4 \pm 1,3)$ liberaram mais flúor na água; o Vitremer $(7,4 \pm 7,1)$, Fuji II LC $(5,7 \pm 4,7)$ e o Freedom $(2,1 \pm 1,7)$ no $\mathrm{pH}$ 4,6. A microdureza e liberação de flúor dos materiais restauradores estudados variaram de acordo com o meio de imersão.

\section{ACKNOWLEDGEMENTS}

This study was supported by CAPES. The authors thank BISCO and SDI for donation of some materials used in the research.

\section{REFERENCES}

1. Okada K, Tosaki S, Hirota K, Hume WR. Surface hardness change of restorative filling materials stored in saliva. Dent Mater 2001;17:34-39.

2. Carvalho AS, Cury JA. Fluoride release from some dental materials in different solutions. Oper Dent 1999;2:14-19.

3. Turssi CP, Hara AT, Serra MC, Rodrigues AL Jr. Effect of storage media upon the surface micromorphology of resinbased restorative materials. J Oral Rehabil 2002;29:864-871.
4. Sales D, Sae-Lee D, Matsuya S, Ana ID. Short-term fluoride and cations release from polyacid-modified composites in a distilled water, and an acidic lactate buffer. Biomaterials 2003;24:1687-1696

5. Nicholson JW, Czarnecka B. The release of ions by compomers under neutral and acidic conditions. J Oral Rehabil 2004;31:665-670.

6. Gandolfi MG, Chersoni S, Acquaviva GL, Piana G, Prati C, Mongiorgi R. Fluoride release and absorption at different $\mathrm{pH}$ from glass-ionomer cements. Dent Mater 2006;22:441-449.

7. Yoda A, Nikaido T, Ikeda M, Sonoda H, Foxton RM, Tagami J. Effect of curing method and storage condition on fluoride ion release from a fluoride-releasing resin cement. Dent Mater J 2006;25:261-266.

8. Karantakis P, Helvatjoglou-Antoniades M, TheodoridouPahini S, Papadogiannis Y. Fluoride release from three glass ionomers, a compomer, and a composite resin in water, artificial saliva, and lactic acid. Oper Dent 2000;25:20-25.

9. Featherstone JDB, O’Reilly MN, Shariati M, Brugler S. Enhancement of remineralisation in vitro and in vivo. In: Factors relating to demineralisation and remineralisation of the teeth. Leach SA (Editor). Oxford: IRL; 1986. p. 23-34.

10. Serra MC, Cury JA. The in vitro effect of glass-ionomer cement restoration on enamel subjected to a demineralization and remineralization model. Quintessence Int 1992;23:143147.

11. Ten Cate JM, Buijs MJ, Damen JJ. pH-cycling of enamel and dentin lesions in the presence of low concentrations of fluoride. Eur J Oral Sci 1995;103:362-367.

12. Vieira AE, Delbem AC, Sassaki KT, Rodrigues E, Cury JA, Cunha RF. Fluoride dose response in $\mathrm{pH}$-cycling models using bovine enamel. Caries Res 2005;39:514-520.

13. Algera TJ, Kleverlaan CJ, Prahl-Andersen B, Feilzer AJ. The influence of environmental conditions on the material properties of setting glass-ionomer cements. Dent Mater 2006;22:852-856.

14. Ellakuria J, Triana R, Mínguez N, Soler I, Ibaseta G, Maza J, García-Godoy F. Effect of one-year water storage on the surface microhardness of resin-modified versus conventional glass-ionomer cements. Dent Mater 2003;19:286-290.

15. De Moor RJ, Verbeeck RM. Changes in surface hardness of conventional restorative glass ionomer cements. Biomaterials 1998;19:2269-2275.

16. Rezk-Lega F, Ogaard B, Rolla G. Availability of fluoride from glass-ionomer luting cements in human saliva. Scand J Dent Res 1991;99:60-63.

17. Silva KG, Pedrini D, Delbem AC, Cannon M. Effect of $\mathrm{pH}$ variations in a cycling model on the properties of restorative materials. Oper Dent 2007;32:328-335.

18. Chan WD, Yang L, Wan W, Rizkalla AS. Fluoride release from dental cements and composites: a mechanistic study. Dent Mater 2006;22:366-373.

19. De Moor RJ, Martens LC, Verbeeck RM. Effect of a neutral citrate solution on the fluoride release of conventional restorative glass ionomer cements. Dent Mater 2005;21:318323.

20. Yan Z, Sidhu SK, Mahmoud GA, Carrick TE, McCabe JF. Effects of temperature on the fluoride release and recharging ability of glass ionomers. Oper Dent 2007;32:138-143.

Accepted October 2, 2007 